\title{
Taren, eren e panton: poetnicidade oral Macuxi
}

Devair Antonio Fiorotti ${ }^{1}$

Para o índio macuxi Caetano Raposo

(in memorian)

A priori, a primeira referência ao termo literatura oral foi feita por Paul Sébillot (1846-1918), em seu Littérature orale de la Haute Bretagne (1881). Vitor Manuel de Aguiar e Silva (2000) destacará que, mesmo o termo literatura, com os significados que conhecemos atualmente, somente se estabeleceu em meados do século XVIII. Até então, quando se desejava tratar da arte oriunda da palavra, eram utilizados termos como poesia, eloquência, verso e prosa (Silva, 2000). Os indígenas Macuxi nomeiam suas narrativas de panton.

"Tudo aquilo ali, panton. Isso que você tá querendo chama panton" afirma em entrevista ${ }^{2}$ Seu Severino, ${ }^{3}$ ancião macuxi da comunidade São Jorge. Depois, ele insiste em esclarecer o que estava falando: "Aí lá vem o jabuti, na onça, né? Hã, panton, história, nós chamamos panton, panton." Em outro momento: "Onça abriu a boca lá e o jabuti: Pouuuu, na boca dele, pegou na testa e a onça morreu. Ele comeu a onça, perdeu a onça, onça perdeu pro jabuti. É a história, panton." Durante toda narrativa, ao se referir a mitos de origem ou mesmo fábulas, a palavra usada era sempre história, que ele estava contando história. A esse respeito, fui alertado por uma liderança indígena, há nove anos, quando ainda estava providenciando a autorização para iniciar minhas pesquisas. Ela me disse: "isso que você chama de mito, fábula, é a nossa história."

A nomeação de panton dada por um Macuxi é muito importante para os objetivos deste texto, que defende as artes orais macuxi e

\footnotetext{
${ }^{1}$ Doutor em literatura e professor da Universidade Estadual de Roraima (UERR) e da Universidade Federal de Roraima (UFRR), Boa Vista, RR, Brasil. E-mail: devair.a.fiorotti@gmail.com

${ }^{2}$ Todas as entrevistas citadas neste artigo foram realizadas por Devair Fiorotti no âmbito do Projeto Panton Pia', desenvolvido na Universidade Estadual de Roraima com financiamento do CNPq. O autor agradece a Maria Georgina dos Santos Pinho e Silva e Huarley Mateus do Vale Monteiro, pela colaboração como assistentes para as entrevistas; a Abner Silva, Ana Maria Alves de Souza e Eliana Almeida e Eleonor Cravo, pela transcrição dos áudios; e a Airton Vieira, Carmem Véra Nunes Spotti, Ana Maria Alves de Souza e Sonyellen Fonseca Ferreira, pela conferência de fidelidade.

${ }^{3}$ Entrevistado em 5 de outubro de 2011, em São Jorge (Terra Indígena Raposa Serra do Sol, Pacaraima, Roraima).
} 
consequentemente dos povos do circum-Roraima, ${ }^{4}$ em virtude da interligação histórica entre esses povos, destacadamente os Macuxi, Taurepang, Ingaricó, Wapixana. Além de panton (plural pantonkon), apresentarei o taren (plural tarenkon), palavras encantadas de cura; e o eren (plural erenkon), cantos indígenas. Defendo que essas três categorias são ainda hoje as principais representantes das artes orais macuxi. Essa etnia pertence ao tronco linguístico caribe, que é a predominante em Roraima. Além de Roraima, há Macuxis na Venezuela e na Guiana Inglesa. ${ }^{5}$

Ao propor estudar as artes orais dos Macuxi, algo marca a proposta: a arte da palavra nascida da oralidade e não da escrita, que é predominante nas redes de ensino do fundamental ao universitário, ou mesmo na relação mais ampla ocidental da literatura relacionada à escrita. Eric Havelock, em A musa aprende a escrever (1996), apontou as mudanças ocorridas na Grécia, mudanças de uma tradição fundada na oralidade que começa sofrer a presença da escrita. Em relação ao projeto que coordeno, Panton Pia', ${ }^{6}$ essa é uma informação crucial: praticamente todos os narradores estão vivendo nesse momento de presença da escrita, muitos não foram à escola e, quando frequentaram, têm dificuldades para escrever os próprios nomes.

Esses narradores vivem um processo de letramento, sim, mas um letramento ainda rudimentar se comparado com o de pessoas que frequentaram a escola de forma regular e que cursaram uma universidade. Pertencem ao que Walter Ong (2002) chamou de

\footnotetext{
${ }^{4}$ Segundo Butt-Colson (1985, p. 104, tradução nossa), o termo circum-Roraima pertence a Cesáreo de Armellada, pesquisador e missionário da Venezuela. Butt-Colson esclarece: "É um termo de referência útil, curto, que denota a região das terras altas e baixas localizadas no entorno do monte Roraima, onde os povos Kapon e Pemon mantêm suas famílias tradicionais".

${ }^{5}$ Para conhecer mais sobre os Macuxi, visite o site "Povos indígenas no Brasil", mantido pelo Instituto Socioambiental (ISA). Disponível em: <https://pib.socioambiental.org/pt/povo/macuxi/734>.

${ }^{6}$ Iniciado em 2007, primeiramente, o projeto registrou 29 narradores indígenas de 17 comunidades da Terra Indígena São Marcos. Em 2014, foram concluídas as entrevistas de mais 10 narradores, de seis comunidades, na Terra Indígena Raposa Serra do Sol. Os narradores eram 27 homens e 12 mulheres, assim distribuídos por etnia: 24 macuxi; seis taurepang; seis wapishana; uma indeterminada. Entre esses, merece menção uma etnia cuja tribo enquanto tal não mais existe: uma sapará; e outro que menciona wapixana e sua relação com o nome karapiwa, sinônimo de wapishana ou mesmo da mistura de wapixana com macuxi (Oliveira, 2014). Na terceira fase, iniciada em 2015, o projeto passou a registrar e analisar cantos, rezas e superstições de indígenas dessas duas terras. Desde 2007, o projeto é financiado pelo CNPq. A metodologia de coleta e trato com as narrativas sustenta-se principalmente na história oral (Alberti, 2004).
} 
letramento secundário, em que já há um contato com a realidade escrita, por mais que seja incipiente, sendo que, no primário, não haveria contato algum. Zumthor (1993) classifica em três níveis a relação oralidade-escrita: $i$ ) oralidade primária e imediata, em que não haveria contato algum com o letramento, sendo presente somente em sociedades isoladas; ii) oralidade mista, ponto em que o oral e o escrito coexistiriam, contudo a influência da escrita seria parcial; e iii) oralidade segunda, oriunda de uma sociedade letrada, variando de acordo com a época, as regiões, as classes sociais e os indivíduos.

Entre os entrevistados, não há um conceito de literatura, por exemplo, como concebemos na academia e mesmo em relação a pessoas adequadamente escolarizadas. Sempre que um entrevistado mais antigo entendia o que eu queria, ao perguntar sobre as lendas e mitos, como Seu Severino da comunidade São Jorge, na Raposa Serra do Sol, ele repetia: isso é panton, professor, é história. No dia a dia dos 37 indígenas entrevistados, há ainda de forma predominante, e não exclusiva, a presença da oralidade relacionada a suas artes verbais. Para os entrevistados, a escrita se resume a documentos oficiais e necessários à garantia de seus direitos, mas poucos efetivamente conseguem ler esses documentos e solicitam que outros o façam, como na hora de assinar a declaração de cedência da entrevista.

A grande maioria dos entrevistados não tem acesso à leitura de livros ou textos escritos como uma prática diária. Fora o contato com a Bíblia e textos oficiais, além de rótulos e algumas placas, eles vivem num mundo, quanto à oralidade, semelhante ao mundo de Homero, em um momento em que a literatura prescindia da escrita e estruturava-se por meio de um processo mnemônico e de criação em ato. $\mathrm{O}$ processo de letramento tem se intensificado, principalmente a partir da chegada da luz elétrica, com a televisão, por exemplo. Contudo, como nossos interlocutores são em sua quase totalidade anciões, ainda apresentam dificuldade para se relacionar com a tecnologia. $\mathrm{O}$ uso de celular nas comunidades visitadas também é praticamente inexistente, pois não há redes de telefonia, apesar de os mais jovens utilizarem-no para ouvir música e fotografar.

Imagino Walter Benjamin diante desses narradores. $\mathrm{O}$ clássico "O narrador" (Benjamin, 1987) foi escrito na década de 1930. De lá para cá, são pelo menos 80 anos. Recordo-me da sensação (e não tenho outra palavra para transcrever) de estar diante do narrador Clemente Flores, da Comunidade Sorocaima I - um contador de histórias no sentido 
tradicional. Lembrar da obra de Benjamim era inevitável; mas no lugar de um narrador definhando, eu olhava assustado para as genialidades daquele narrador na minha frente. ${ }^{7}$ Essa sensação se repetiu inúmeras vezes enquanto registrava as narrativas, as falas encantadas, os cantos dos indígenas do circum-Roraima.

A primeira conclusão a que cheguei foi que o ambiente intelectualizado frequentado por Benjamin diferenciava-se e muito do ambiente de Seu Clemente. Mesmo 80 anos depois, Seu Clemente ainda vivia praticamente isolado: em meio a montanhas e matas, mantendo contato esporádico com pessoas diferentes de sua etnia, os Taurepang. E esse aspecto se confirmou com outros narradores. A segunda, foi a lembrança das minhas leituras de Eric Havelock, dos tempos em que estudava grego. Os da urbe, como eu, como Walter Benjamin, como a maioria dos intelectuais das academias, acabam ignorando a existência de comunidades tradicionais, ainda fundamentadas na oralidade em diferentes níveis, ignorando que nelas há, por exemplo, estruturas textuais poéticas.

Quanto aos narradores do projeto Panton Pia', vale um adendo: os entrevistados do projeto são, em sua quase totalidade, idosos ou têm acima de 50 anos. Eles vieram de uma estrutura de comunidade e de vida indígena diferente da atual. Vivenciaram, no geral, um contar oral de seus pais e avós, sem TV, sem internet, sem telefone, andando a pé, sendo curados com pussangas e pajés. A vivência de formação desses indígenas foi realizada principalmente pela oralidade. A musa nessas comunidades está aprendendo a ler mais sistematicamente de duas décadas para cá.

Mauricio Ostria González (2001), da Universidad de Concepción, no Chile, dirá que a problemática na América Latina em relação à oralidade, face à literatura, pode ser reduzida a quatro questões gerais. A primeira diz respeito à criação verbal em uma cultura tradicional não letrada, as chamadas culturas ameríndias, tal como mencionam Ong (2002) e Zumthor (1993). Levando em consideração esse primeiro aspecto, não se pode dizer que haja, entre os 37 entrevistados, esse perfil de comunidades isoladas, sem contato com letramento.

A segunda problemática, na enumeração de Ostria Gonzáles, relaciona-se às manifestações orais próprias de culturas tradicionais ou populares no interior de uma cultura letrada dominante, subjugada a entornos ocidentalizados. Esse aspecto também foi enumerado por Ong

\footnotetext{
${ }^{7}$ As narrativas dele, já falecido, encontram-se no livro Panton Pia', volume I, ainda inédito.
} 
(2002) e Zumthor (1993). Justamente nesse ponto, dentro de minhas considerações em geral, estariam as comunidades das regiões da Raposa Serra do Sol e São Marcos. São comunidades tradicionais no interior de uma cultura letrada e ocidentalizada, principalmente depois da consolidação da BR 174, que liga o Brasil à Venezuela, cortando a Terra Indígena São Marcos e proporcionando à vizinha Raposa Serra do Sol um contato mais rápido e efetivo com não indígenas.

A terceira questão trata da relação entre aspectos orais e escritos dos textos literários (aspectos como harmonias, timbre, ritmo, entonação etc. e as formas gráficas de representação em verso e prosa). Nesse ponto, reside algo caro aos estudos literários: sua impossibilidade de definir seu objeto (Eagleton, 1997; Compagnon, 2012), principalmente de distinguir efetivamente o que é estritamente escrito, sem influência da oralidade. $\mathrm{O}$ que há, em geral, é uma primazia da origem do oral sobre o escrito (Ong, 2002), havendo uma relação estreita entre o oral e o escrito. Isso pode soar estranho, mas há sempre um ponto de encontro: a estrutura da língua e a forma como ocorrem suas representações superficiais de coincidências e divergências. A escrita não é mera cópia da fala, mas dizer que elas não se entrecruzam seria um absurdo. Ainda vale destacar, nesse ponto, as tentativas de autores que buscam trazer aspectos da oralidade para o texto literário escrito. Casos emblemáticos como o de Guimarães Rosa dispensam aprofundamentos. Desde o modernismo brasileiro, exemplos desse procedimento abundam na literatura brasileira.

Já a quarta questão, para Ostria Gonzáles, seria o problema das diversas formas da oralidade e textos escritos literários, o que González chama de oralidade fictícia. Nesse ponto, penso que o autor se refere ao estudo dos tipos e gêneros literários, numa dinâmica discursiva que está presente tanto em textos escritos quanto em textos orais, sejam eles fictícios ou não. Esse dinamismo indubitavelmente impõe-se como um problema, principalmente se eles, os orais e escritos, interligarem-se propositalmente, como se tem visto na literatura contemporânea.

Acrescento a essa discussão a questão do cânone nacional. Durante quase toda existência da literatura brasileira, por exemplo, textos de origem oral foram desconsiderados - simplesmente não estão presentes em livros didáticos, em compêndios de literatura nacional. Trabalhos como os de Câmara Cascudo e parte dos de Monteiro Lobato representam exceção no compêndio da literatura nacional. 
Por trás desse descaso, há um processo de desvalorização e mesmo preconceito. A pergunta que faço é: quem são os cantores, dominadores das palavras encantadas, os contadores de histórias? De que comunidades se originam e como estão essas comunidades em relação às elites mais favorecidas de nosso país? De forma geral, quando falamos em tradição oral, já pensamos em pessoas que vivem à margem e que, na maioria das vezes, têm sua própria tradição ignorada em relação aos processos culturais, educacionais e econômicos das elites nacionais.

Inicialmente, trouxe uma discussão mínima acerca dos problemas sobre a presença da oralidade e suas dimensões de contato com a escrita em nossos dias. Principalmente, entendo que há um processo de descaso das elites culturais, educacionais e econômicas em relação à arte oral, oriunda das comunidades tradicionais, situadas à margem dos interesses dessas elites - o que esbarra no estabelecimento do cânone. Como afirma Antonio Risério (1993, p. 25): “Não há povo que não ostente, no elenco dos seus signos mais expressivos, objetos de linguagem correspondentes ao que, em nosso mundo, chamamos poesia".

A partir, principalmente, da experiência com a cultura macuxi, povo pemón de origem Caribe, e de narradores dessa etnia, passo a apresentar três aspectos da retórica, de falas estilizadas e da poética macuxi: taren, eren e panton. Não me aprofundarei em aspectos etnológicos da cultura desse povo, mas em características inerentes a essa poética oral e seus usos na comunidade.

Essa é uma apresentação mínima dessa poética, e como tal, algumas questões e mesmo análise dos textos ficarão em suspenso, passíveis de aprofundamento em oportunidade posterior. Nesse ponto, vale ainda um esclarecimento: os textos aqui apresentados foram submetidos a um processo de transcrição, tradução e transcriação ${ }^{8}$ quando necessário. Infelizmente, se perde muito da performance nesse processo, contudo o máximo da oralidade dos interlocutores possível foi preservada nesses textos.

\section{Taren}

O taren é tido por Armellada e Napolitano (1975) como gênero literário maior entre os Pemon, dos quais os Macuxi fazem parte. $\mathrm{O}$

\footnotetext{
${ }^{8}$ Termo cunhado por Haroldo de Campos (ver, por exemplo, Campos, 2011).
} 
tarenpokon é o rezador, e ele possui papel bem definido na comunidade: o de curar casos relacionados principalmente ao corpo como diarreia e dor de cabeça; bem como são usados, por exemplo, durante as plantações, para que a produção seja boa. Também ouvi de uma interlocutora, da comunidade do Maturuca, na Terra Indígena Raposa Serra do Sol, que ela teria ficado doente por causa de uma pussanga, de uma reza lançada por uma vizinha. $O$ tarenpokon não bate folha, ${ }^{9}$ isto é, em uma sala escura, ele se distingue, nesse sentido, do pia'san ou pajé. O pia'san contata os espíritos bons para promover a cura (Rabelo Filho e Araújo, 2015) - ou não, já que os objetivos do pajé nem sempre são tão claros, assim como sua relação com o Canaimé (Whitehead, 2002). Esse trabalho noturno, mas amplo, de viajar e conversar com os espíritos, por exemplo, cabe ao pia'san. $\mathrm{O}$ tarenpokon pronuncia palavras mágicas, encantadas, e por essas palavras nasce a cura, mas também pode indicar ervas e poções, assim como o pajé.

O texto a seguir é um taren de Vitor da Silva, ${ }^{10}$ comunidade do Ingarumã, na Terra Indígena São Marcos.

Urî sane tî, urî sane tî Insikiran pia

Sene moi' e'tarîmo'tî pî wai tî piri'ya enato'pe

I' pî iteparan era'tisa, o'ma ya ira'tisa, paran ya yapî́sa

Yannanî pî pî wai tî urî tî Insikiran pia tî

Insikiran pia ya imasa'kapî mantî

Anike pia ya i'masa'kapî mantî

Makunaimî pia ke imasa'ka pî wai tî

tumasi yenî pan nî pî̀ wai tî

Kumi ya wanî tî ke, yennî pan nî pî́ pi wai tî, i'masa'kapî wai tî

Inîrî piri ya para wanî ton pe para, i'masa'kapî wai tî,

Urî tî Insikiran pia, Anike pia se tî,

Makunaimî pia ke i'misa'kapî wai tî

Inîrî piri ya para enato' pe para i'masa'kapî wai tî urî sane tî

Insikiran pia se tî. ${ }^{11}$

\footnotetext{
${ }^{9}$ Os pajés arrancam dois maços de folhas específicos para isso e, em geral, sentados, ficam batendo as folhas no chão, ao mesmo tempo que as levantam e fazem movimentos específicos do processo de pajelança. Praticamente não há mais pajés na região estudada, e os que existem já estão em um processo de sincretismo avançado com religiões ocidentais. Um dos pajés que visitei possuía uma bola de cristal, outro, sobre a mesa, várias imagens de santos.

${ }^{10}$ Entrevistado em 20 de março de 2009, na Comunidade Guariba (Terra Indígena Alto São Marcos, Pacaraima, Roraima).
} 
Eu sou eu, eu sou eu filho do Insikiran.

Estou rezando este menino pra ele ficar bom,

Porque a doença virou nele, bicho virou ele, doença pegou.

Fiz ele melhorar. Sim, sou filho do Insikiran.

O filho do Insikiran fez ele levantar, filho de Anikê fez ele levantar.

Com filho de Makunaima fiz ele levantar, fiz ele comer.

Com pussanga fiz ele ficar esperto, com Makunaima, com

pussanga,

Com minha comida, com minha peneira.

Com meu mel fiz ele ficar bom.

Fiz ele levantar pra ele nunca mais ficar doente, fiz ele levantar.

Sou eu filho de Insikiran, filho de Anikê, filho de Makunaima.

Fiz ele levantar, para nunca mais ele ficar doente.

Fiz ele levantar, sim, sou eu filho do Insikiran. ${ }^{12}$

Entre o passado e o presente, nasce esse taren: "Eu aprendi com eles, com os antigos, eu não disse que eu não aprendo muito, mas eu aprendo oração" - disse Seu Victor. Mas não nos iludamos, como já registrou Armellada, que como poucos conheceu os Pemon:

Nossos indígenas atuais são tão inteligentes como eram os antigos ou mais que eles; não são meros repetidores, não são uns burricos que transportam valores que não conhecem. O mundo mudou e continua mudando, mudaram os povos, entraram em simbiose com eles e tudo isso se reflete em sua língua desde o léxico até o ápice de suas criações literárias (Armellada e Napolitano 1975, p. 10).

Chama atenção no texto a invocação aos irmãos já famosos na literatura brasileira, desde o lançamento de Macunaíma, de Mário de Andrade: Makunaima, Insikiran e Anikê. Discursivamente, o tarenpokon se coloca como filho desses irmãos: "Sou eu filho de Insikiran, filho de Anikê, filho de Makunaima". Evoca como filho e trabalha com eles para a

\footnotetext{
${ }^{11}$ A escrita da língua macuxi que utilizo aqui não é fonética, mas o padrão atual mais utilizado na região estudada por mim, inclusive utilizada em boa parte das escolas da região. Há certo conflito entre uma tentativa oriunda dos linguistas, mais fonética, e a prática em sala de aula. De antemão esclareço que este não é um trabalho voltado à linguística, mas, principalmente, aos estudos literários.

12 Todos os textos literários reproduzidos aqui, bem como as falas dos narradores pertencem ao projeto Panton Pia', já mencionado. A tradução é minha e de Rivelino Pereira de Souza.
} 
cura: "Com filho de Makunaima fiz ele levantar". No taren, pode-se ver também a pussanga, medicamento caseiro, feito com ervas - mas mais que isso, a pussanga envolve métodos, como "curar" uma criança para ser caçador, pescador, curar a boca da menina para preparar o caxiri (bebida feita de mandioca cozida, de batata, cara) e o pawa (bebida fermentada de mandioca com significativo teor alcoólico). Observa-se, ainda, que ele fez a criança levantar com sua comida, com sua peneira, com seu mel. Esses aspectos remetem à vida mais comum da comunidade. Os objetos utilizados são do dia a dia e relacionados ao fazer diário da comunidade: comida, peneira, mel. O taren é encerrado destacando novamente de quem o tarenpokon é filho, bem como sua origem mítica e divina: os makunaima.

Deborah Goldemberg (2009, p. 57) defende que a poética ameríndia é "em geral direcionada para funções culturais diversas, sejam elas cosmológicas, educacionais, pedagógicas ou bélicas, sejam elas conscientes de serem isso, poéticas, ou não". Essa fala destaca bem o que vemos nos tarenkon: a princípio, há uma relação direta do taren apresentado com a vida da comunidade, a origem do povo macuxi, ao mesmo tempo essa poética não se apresenta como tal, mas, sim, possui uma função clara na comunidade, como palavras encantadas de cura, auxiliadas pelos conhecimentos curativos do tarenpokon.

Esse outro taren, pronunciado por José Melquíades Peres, ${ }^{13}$ possui evocação similar. Diz ele que "Eu vou rezar assim. Assim, se você tá com filho novo, tá pequenininho, não pode trabalhar, senhor não pode trabalhar, ninguém pode trabalhar se não for rezado, rezado no nome dos dois." Entre os indígenas, o homem guarda o resguardo por tempo significativo. $\mathrm{O}$ tarenponkon auxilia para que o homem possa exercer suas funções na comunidade. Diz ele assim:

Maasa pia, mansi pia, mîn pe awanî tane

Wa wa pia' awanî tane esenka man pî wai tî

Urî sa'ne tî Insikiran pia tî

Urî sa'ne tî Insikiran pasha tî

Anike pasha tî mîrîrê

I'kareme kî waitî

Shini ekaran popî waitî

Taura pî awanî konya

${ }^{13}$ Entrevistado em 13 de abril de 2009, em Aleluia (Terra Indígena Alto São Marcos, Pacaraima, Roraima). 
Waaka pî awanî konya

Mansi epo'rî nîmai

I'kone ka pî wai tî

Urî sa'ne kin tî

Insikiran pashi tî

Anike pashi tî

Enquanto a fonte [a vagina] está ainda de resguardo

Enquanto tá perto o bebê, vou trabalhar.

Eu sou filho do Insikiran!

Eu sou filha do Insikiran!

Eu sou filha do Anike!

Estou dizendo pra você

Estou perguntando pra você

Quando estiver com faca

Quando estiver com machado

Pro mal não encontrar o bebê

Pra nunca encontrar

Estou guardando, estou guardando o bebê

Mas eu estou desprotegido

Eu sou irmã do Insikiran

Eu sou irmã do Anike.

Deixemos que o próprio José Melquíades Peres explique o taren:

Tá dizendo assim: "Você Insikiran, você Aninkê, meu filho tá novo. Nasceu hoje, mas eu vou trabalhar. Vou usar terçado, vou usar machado, vou usar e fazer minha casa." Com isso, nunca vai acontecer a doença, como se fosse o quebrante pra prejudicar minha criança, não. Aí a gente assopra. Depois você pode ir trabalhar, pode pescar, pode furar couro. Pode fazer tudo. Porque aí, se piranha morder, se a arraia ferrar o senhor, a gente reza chamando ele, chamando vagina de mulher. Não tem outro melhor, chamando ele. Tudo oração através desse Insikiran e Aninkê, eles têm muita oração, eu tenho essas orações dele. Com isso aqui eu combato meus filhos. Ele mata cobra grande, ele mata qualquer coisa. Eu rezo logo. Eles estão aí de prova, que isso não acontece mesmo. Eu digo: “Pode fazer, faça aí!" Agora eu só não quero que eles matem os bichos sem me avisar. Ầs vezes mata criança deles, eu não sei, eu não estou na hora, aí mata mesmo, pra nós é assim. Se matar um gato, uma onça, e uma criança se tiver tamanho desse aqui, aquela dali [uma criança], se pai dela 
matar uma onça, se não tiver rezador, [filhos de Macunaima] matam ela [a criança]. Chega e mata filho. Se matar uma cobra grande, dessa grossura como se fosse sucuriju e não tiver oração, derruba essas crianças todinhas. Aí vão pro hospital, mas lá não tem jeito se não for oração. A história do Aninkê com Insikiran foi assim, os filhos de Macunaima. ${ }^{14}$

\section{Eren}

Erenkon são cantos em macuxi. ${ }^{15}$ Os erenkon apresentam uma estrutura complexa na região do circum-Roraima, em geral estão relacionados à dança. Existem vários tipos de erenkon: parixara, tukui, areruya, marapá, ware'pan, manau'ã - no caso desses dois últimos, por exemplo, só ouvi mencioná-los, mas não conheci ainda nenhuma música, por mais que indagasse aos interlocutores. Enquanto um complexo artístico, o parixara, por exemplo, envolve dança, instrumentos como kewei (chocalho), sampura (tambor), kamaini (flauta grande de embaúba); o tukui, além desses instrumentos, wana e ruwe (tipos de flautas pequenas). Não há um limite rígido para usos desses instrumentos. Essas duas danças, parixara e tukui, podem ser dançadas juntas: num círculo maior, externo, o parixara, que possui ritmo mais lento; o tukui, na parte interna, sendo dançado e cantado mais rápido.

Além da dança e da música, há os trajes, em geral saias feitas de fibra de inajá (Maximiliana maripa) e buriti (Mauritia flexuosa) ou mesmo coco, na atualidade, além de trajes feitos com finos bambus e lágrimas de Nossa Senhora (Coix lacryma-jobi), como na foto 1. Pelo corpo, há pinturas diversas, de jenipapo e urucum, principalmente, e num período mais remoto, os indígenas dessa região pintavam-se com tawa, com tabatinga. A festa poderia durar vários dias (hoje, raramente há festas exclusivamente com músicas indígenas), comunidades vizinhas eram convidadas, inclusive as de etnias distintas. Para acompanhar, muita bebida, muito pawa e pawari, conhecidos como pajuaru nos dias atuais. A pawa é preparada no chão

\footnotetext{
${ }^{14} \mathrm{Na}$ região estudada, há variação: às vezes Insikiran e Aninkê são irmãos, em outras, filhos, como nessa fala de Melquíades Peres.

${ }^{15}$ Erenkon podem ser também cantos de pássaros, cantos no geral. Um trabalho completo (com explicação teórica, cantos, tradução, partituras e CDs anexos) sobre os erenkon macuxi e taurepang foi aceito para publicação no Museu do Índio, do Rio de Janeiro (no prelo).
} 
e feita de mandioca, sendo mais forte e escura; a pawari é preparada sobre um jirau e um pouco mais clara. Além disso, é servido muito caxiri, que depois de fermentado fica levemente alcoólico. Im Thurn (1883, p. 329) chamou essas festas de "pawari feasts", festas do pajuaru. Ele relata que uma quantidade enorme de bebida era consumida enquanto se dançava por dias seguidos.

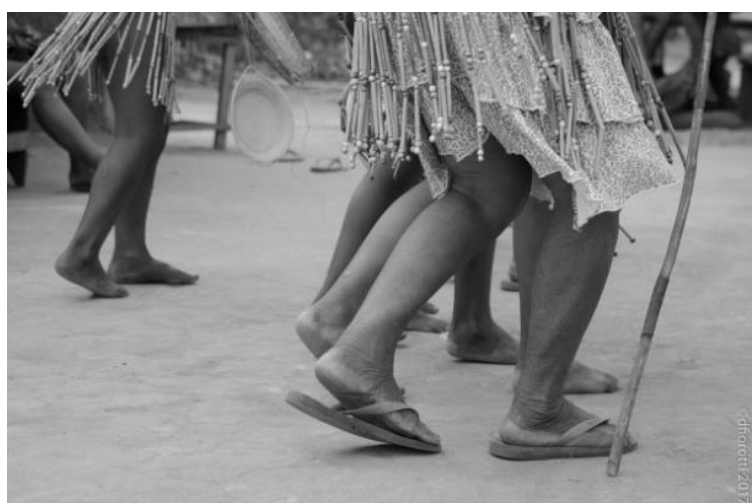

Figura 1 - Dança do parixara

Foto: Devair Antonio Fiorotti.

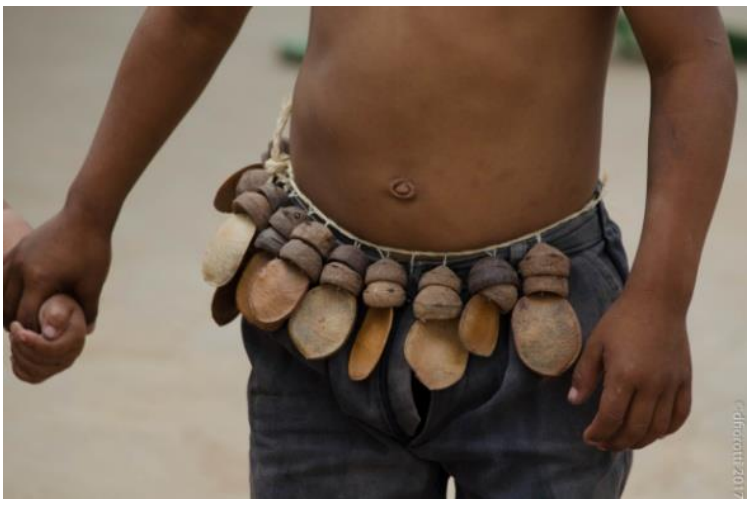

Figura 2 - Criança com adornos musicais

Foto: Devair Antonio Fiorotti. 
Apresento neste artigo um parixara e um tukui, ciente do deslocamento que é feito de seu contexto originário, mais complexo, da dança, da festa indígena. Resumidamente, parixara - pariisara em macuxi - estaria relacionado em geral à fartura das colheitas, da caça ou da pesca e a datas comemorativas. Koch-Grünberg (2006, p. 79) comenta que o "parischerá é a dança dos porcos e de todos os quadrúpedes". Nos dias atuais, o parixara é usado principalmente em ocasiões comemorativas ou mesmo festejos como representação do que era o parixara, sua história. Hoje se fala em grupos de parixara, assim como grupos de dança, no sentido usado pelos não indígenas. Nas comunidades de interlocução, em sua quase totalidade, o parixara não faz mais parte de um uso coletivo como era no passado. Tornou-se, ainda, sinônimo de dança indígena, incluindo, às vezes, até outras músicas tradicionais, como tukui, por exemplo, que são dançadas como sendo parixaras.

$\mathrm{Na}$ dança indígena, o corpo dança e toca (ver fotos 1 e 2). Muitas vezes o dorso, os tornozelos, os joelhos, a cintura são adornados com enfeites musicais que soam, que cantam. Ao dançar, a marcação rítmica do corpo faz soarem os adereços sonoros. O nome pariisara pode ser relacionado ao radical pari, que atualmente significa capim, principalmente um capim conhecido como rabo-de-burro devido ao formato de sua floração. Tiago Simplício Napoleão, indígena macuxi da comunidade Napoleão, na Raposa Serra do Sol, informou que esse capim era usado também para os enfeites utilizados na dança do parixara, confeccionados também com folhas novas de inajá e buriti geralmente desfiadas. As folhas dessas plantas, após desfiadas, também se parecem com o capim seco.

Assim Koch-Grünberg descreve em 1911 a chegada de um parixara, na comunidade Koimélemong, entre as terras indígenas (TIs) São Marcos e Raposa Serra do Sol, região do Surumu, em Roraima:

Os dançarinos chegam numa longa fila, vindos de longe na savana. É uma espécie de dança de máscaras. Usam singulares adornos de cabeça, feitos de folhas de palmeira inajá, que cobrem parte do rosto. Longos penduricalhos do mesmo material envolvem o corpo e cobrem as pernas. Eles tiram abafados sons uivantes de tubos feitos da leve madeira embaúba, que têm na parte da frente todo tipo de figuras de madeira, peixes também, pintadas de várias cores, enquanto agitam os instrumentos para cima e para baixo. Chegam dançando, dobrando os joelhos. A cada dois passos, batem com o pé direito no chão, dobrando ligeiramente o tronco para frente (Koch-Grünberg, 2006, p. 77). 
Essa chegada, ao retornar de outras comunidades ou mesmo de uma caça ou pesca comunitária maiores, é descrita por vários dos interlocutores do projeto Panton Pia' como um dos pontos altos da festa, em que eles chegam dançando e em geral ornados. Koch-Grünberg também enfatiza o momento da chegada dos visitantes (2006, p. 77), que são recepcionados por mulheres com pawa. Quando a chegada é de indígenas de outras comunidades, pode haver uma conversa entre os líderes, descrita como formal e monótona por im Thurn (1883, p. 323). Na chegada, não se distingue quem está ornado para quê. Como veremos, os dançarinos de tukui ocupavam uma situação diferenciada dentro da manifestação cultural, inclusive com ornamentos e mesmo instrumentos distintos. Essa descrição de Grünberg e de onde ela surgiu também é importante, pois os cantores dos cantos aqui apresentados, Terêncio Luiz Silva e Zenita de Lima, pertencem à região em que foi feito registro - inclusive ele estudou na missão religiosa instalada nos arredores do Surumu, missão mencionada e visitada pelo próprio Koch-Grünberg.

O texto dos cantos foi trazido por Terêncio Luiz Silva, indígena macuxi da região das serras, da comunidade Ubaru, a dois dias a pé da cidade de Pacaraima, Roraima, Brasil. Terêncio Luiz Silva é um sábio que como poucos conhece os cantos dessa região. Dele foram registrados 79 cantos, além de ser o principal interlocutor para a tradução.

O parixara, enquanto música, repete a frase geradora, aquela que deu origem ao canto, repete por quatro vezes. Sobre essa frase é feita a tradução. A versão atual dos cantos, com todas as repetições paralelísticas, foi estabelecida por mim a partir da audição dos cantos. Principalmente estabeleci outros objetivos além da mera inclusão da letra: conferir movimento (mesmo que mínimo, se comparado à dança com a música); criar imagens que, entre outras coisas, pudessem dialogar com os poemas em português; e imprimir certo ritmo aos versos e estrofes. Buscando isso, alguns versos foram dispostos minuciosamente, inclusive espacialmente no formato do áudio, seguindo sua partitura, como no parixara 16:

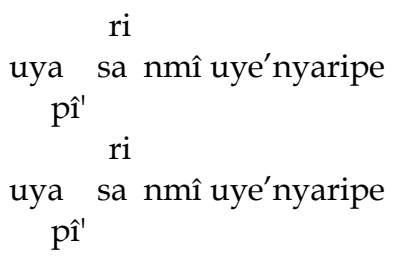


A leitura da frase deve seguir a ordem de surgimento das palavras, levando em consideração a que surgir primeiro da esquerda para direita. O verso ficaria assim: uyapî' sarinmî uye'nyaripe. Além disso, muitos versos são modificados espacialmente, mas há versos iguais na estrofe, que facilitam a leitura por analogia. Apresento o parixara 16:

kîrî-kîrî worantî uutî na'mî kîrî-kîrî worantî uutî na' mî

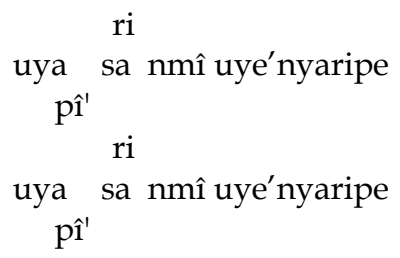

kîrî-kîrî worantî uutî na' mî kîrî-kîrî worantî uutî na'mî

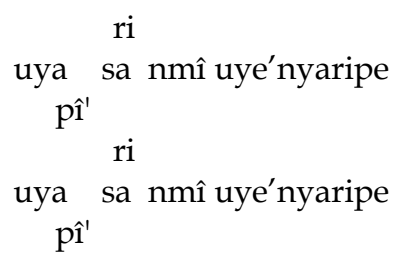

kîrî-kîrî worantî uutî na' mî

kîrî-kîrî worantî uutî na'mî

ri

uya sa nmî uye'nyaripe

pî̀

ri

uya sa nmî uye'nyaripe

pî́

kîrî-kîrî worantî uutî na' mî kîrî-kîrî worantî uutî na' mî

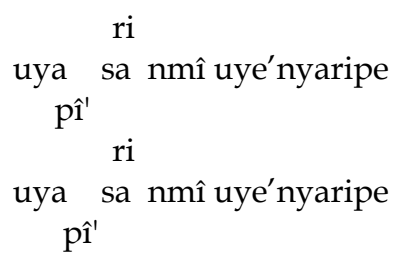




\title{
parixara 16
}

\author{
estou indo \\ como periquito \\ meus braços são minhas asas
}

Por uma questão estética e estilística, e também em função do trabalho visual com os cantos, tanto a tradução quanto a letra da música não apresentam uso de pontuação nem de letra maiúscula, com raras exceções para o uso de caixa alta. Ainda, a separação com espaço entre muitas estrofes foi sacrificada em prol da construção de imagens a partir das letras dos cantos. Destaca-se no parixara a imagem poética: o indígena chegando, dançando, com braços abertos como um periquito.

Já o tukui - ou tukuxi (como presente em algumas músicas, um uso mais antigo da palavra) - significa beija-flor, e consiste em cantos em geral relacionados à sabedoria dos pajés, voltados a intervenções na natureza, como chamar chuva e acalmar trovões. Vale acrescentar que também eram dançados coletivamente. Armellada e Salazar (2007, p. 148 e p. 203) dizem que se formam duas rodas concêntricas, em que o tukui era dançado por fora enquanto o parixara por dentro, além de se usar tambor e pitos de taquara. Não há muita precisão sobre quem dançava por fora ou por dentro (como já disse o oposto anteriormente, a partir de um interlocutor da região do Maturuca).

O tukui está relacionado à flora, à floração, e sua dança pertencia principalmente aos guerreiros e pajés. Esses cantos predominam entre os registros feitos com Terêncio Luis Silva: são 40 de um total de 79 . Além de saias de fibras como buriti, seus dançarinos usavam como ornamento beija-flores ou outros pássaros dessecados. Esses pássaros eram usados como ornamento para cabeça ou eram amarrados como enfeite na ponta de um pequeno pedaço de pau.

De acordo com Koch-Grünberg, o tukui é a dança de todos os pássaros, principalmente beija-flor, e de todos os peixes. O etnologista alemão narra que as pessoas

usam somente a tanga e estão pintados com motivos artísticos ou simplesmente besuntados com argila branca, no cabelo também, o que dá a muitos uma aparência extremamente selvagem. Em grupo de dois ou de três, parte deles de braços dados, andam um 
atrás do outro, dobrando os joelhos, batendo com o pé direito no chão. Os homens acompanham sempre o mesmo som de madeira estridente num curto pedaço de taquara (2006, p. 78-79).

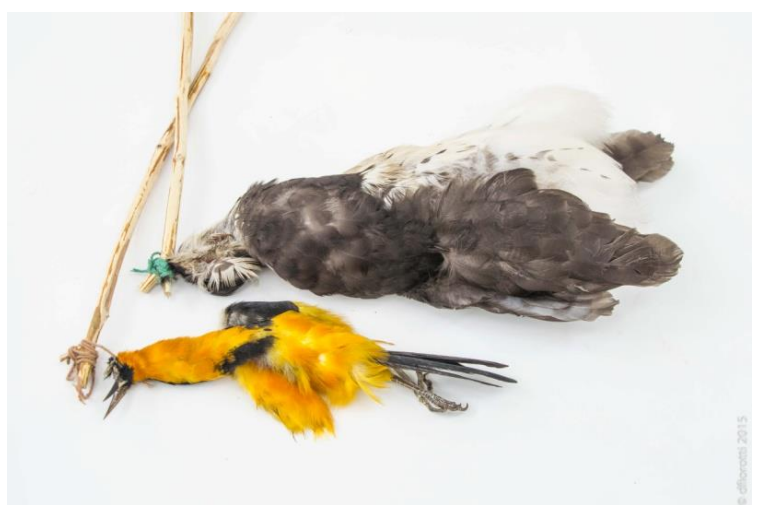

Figura 3 - Pássaro empalhado utilizado na dança.

Foto: Devair Antonio Fiorotti.

Nos dias atuais, praticamente não há mais cantores de tukui, principalmente por causa de sua vinculação com os pajés e seus conhecimentos. Os pajés e suas sabedorias estão em extinção no lado brasileiro, pois são associados à magia pelas religiões fundamentalistas. Diante da presença dessas igrejas, tem sido o ritmo mais atacado. Vários informantes se negaram a falar dele, dispondo-se a comentar somente sobre o areruia e o parixara.

wawini nekutumarî reponi nekutumarî taraure wawini nekutumarî reponi nekutumarî taraure taaa

$$
{ }_{\text {wa wa }}^{\text {ke }} \text { ee } \stackrel{\text { ra }}{\text { ra }}
$$

tawaake tawaake taraure

wawini nekutumarî reponi nekutumarî taraure wawini nekutumarî reponi nekutumarî taraure taaa 
${ }_{\text {wa }}^{\text {wa }} \stackrel{\text { ke }}{\text { ta }}$ rau

tawaake tawaake taraure

wawini nekutumarî reponi nekutumarî taraure

wawini nekutumarî reponi nekutumarî taraure taaa

$$
{ }_{\text {wa wa }}^{\text {ke }} \text { ee }{ }_{\text {ta }}^{\text {rau }}
$$

tawaake tawaake taraure

wawini nekutumarî reponi nekutumarî taraure wawini nekutumarî reponi nekutumarî taraure taaa

$$
{ }_{\text {wa wa }}^{\text {ke }} \text { ee }{ }_{\text {ta }}^{\text {rau }}
$$

tawaake tawaake taraure

\section{tukui 4}

tawaake tawaake

estou dizendo que marreca banha paturi banha com tabatinga no lago

tawaake tawaake

Segundo Terêncio Luiz Silva, os marrecos citados se banham na água suja, barrenta de tabatinga. Os marrecos, na relação da música com o tukui, se enfeitam com a cor branca da tabatinga. O tawa cria contraste na cor avermelhada e mesmo negra desses marrecos, ${ }^{16}$ assim como o tawa cria contraste sobre o cabelo negro, sobre a pele avermelhada do indígena ou enegrecida pelo karutuke, pelo jenipapo, tão presente em vários cantos. Na dança, assim como os patos - pois eles estão a se banhar, a se farfalhar no lago com tabatinga -, os dançarinos faziam

\footnotetext{
${ }^{16} \mathrm{O}$ informante não conseguiu especificar claramente os tipos de marrecos em português. O menor (paturi) deve ser Netta erythrophthalma e o maior Cairina moschata. Essas são aves abundantes no lavrado e mesmo na savana venezuelana.
} 
algo parecido (im Thurn fala do processo imitativo dos indígenas na dança), besuntando-se com tawa, no corpo, no cabelo para dançar, como destaca Koch-Grünberg.

\section{Panton}

A respeito dos índios Pemon - dos quais os Macuxi fazem parte -, em contraposição aos Kapon, Armellada (1975, p. 66) informa que aquele que sabe contos ou lendas não é somente considerado um sábio (patá punín, aquele que conhece o mundo), mas também um rico, um pantón-sak, como quem possui dinheiro, colares ou escopetas. A princípio, e principalmente antes da chegada da luz elétrica, contar histórias era uma tarefa constante e rotineira. Pantonkon são narrativas da vida mítica e mesmo atual. É o ato de narrar experiências e a história do povo Macuxi, um momento em que passado e presente se encontram, em que a convivência entre animais e humanos não se distinguia: os animais eram humanos, falavam, casavam com humanos, bem no sentido em que aponta Viveiros de Castro (2011) sobre o perspectivismo ameríndio.

Trago aqui uma narrativa de Caetano Raposo, falecido em 2016. ${ }^{17}$ A narrativa foi-me narrada em português, apesar de o narrador ser falante de macuxi. A narrativa do lago do Piripiri, na versão aqui apresentada, é inédita, contudo ela já foi registrada, com certas variações, em outras etnias: taurepang, wapixana, tenetehara, palikur, karajá e paumari. Esses quatro últimos, para além do circum-Roraima. ${ }^{18} \mathrm{O}$ registro mais famoso dessa narrativa foi realizado em 1911 por Koch-Grünberg. Naquele momento, ele a registrou com o nome de "A visita ao céu". Há diferenças significativas entre as narrativas, que vão do título ao desfecho; contudo, em geral, preserva-se a visita ao céu feita pelo homem, visitando o mítico Urubu-Rei, de duas cabeças. A escolha dessa narrativa deu-se por dois motivos principais: a técnica narrativa de Caetano Raposo e o processo de fabulação deste panton.

\footnotetext{
${ }^{17}$ Registrada em entrevista a Devair Antonio Fiorotti, no dia 26 de abril de 2014, em Boa Vista, Roraima.

${ }^{18}$ Esse mapeamento e análise estão sendo feitos por Gracinara da Silva Teixeira, aluna do Programa de Pós-Graduação em Letras da Universidade Federal de Roraima (UFRR), sob minha orientação, tendo como ponto de partida a narrativa de Caetano Raposo. Até o momento de publicação deste artigo, a dissertação ainda não havia sido concluída.
} 


\section{Piripiriku'pa [lago do Piripiri]}

Caetano Raposo (CR): Uma vez parente morava sozinho, mas ia sempre na roça dele, todos os dias na roça dele. E na beira do caminho dele tinha uma anta morta. Aí todas às vezes quando ele passava ali, ele via sair um urubu de dentro da anta. "Ai, eu vou pegar esse Urubu e vou entrar também." E ele entrou dentro da anta. Ai lá vem Urubu, lá dentro ele pegou Urubu. Pegou, amarrou e levou pra casa dele e amarrou lá, na estaca da casa, lá. Todo tempo ele ia pra roça, ele chegava, damorida tava pronta.

Devair Fiorotti (DF): O Urubu fazia?

CR: Eh, Urubu fazia, ele não sabia, não. Caxiri tava pronto, terreiro tava limpo. Tudo limpo aí.

DF: Ele casou com ela então?

CR: Eh. Aí "Quem é que faz isso aí?" Mas ele não sabia. Ele chegava ele mesmo se servia com caxiri, com damorida. Aí ele pensando: "Quem é que tá fazendo isso aí?" O Urubu amarrado. Aí um dia ele pensou: "Eu vou ver isso aí. Eu vou enganar ele." Saiu pra roça como de costume, aí Urubu transformou numa mulher. Tirou corda, esquentou damorida, fez o caxiri. Ela fez caxiri, ele trazia [...] a mandioca, o homem da roça, deixava aí, ela mesma fazia. Enterrava, cozinhava o caxiri, beiju, tudo ela fazia. Ele viu, se assustou todinho, se assustou. Aí ele chegou. "Ah, você que fazia isso aí." "Eh, eu mesma." "Então tá bom. Vamos ficar juntos agora." "Tá bom." Ficaram juntos, com o Urubu. Agora, um dia ela disse pra ele "Marido, vamos lá no Piripiripuruka?", lago do Piripiri. "Vamos lá." "Hum, tá." "Umbora." "Tá aqui água pra ti."

DF: A água pro marido.

CR: "Bora?" "Bora." Saíram, ele acompanhando ela. Foi longe, foi alto, alto, alto, alto, alto, alto. Ela perguntou: "Como é que tá Terra aí?" "Tá aniquilada." Subiram, subiram, subiram, subiram, subiram, subiram, subiram "E agora?" "Tá nem que prato." $\mathrm{O}$ mundo, né? Subiram, subiram. "E agora?" "Tá nem que ovo." Subiram, subiram, tavam chegando perto da cidade do Piripiri.

DF: É uma cidade ou um lago? 
CR: Água (eu tô nessa idade). Quando chegaram lá: "Aqui é a casa do papai, do meu pai. Ninguém vê, não, o rei, o Urubu-rei." Ela era filha do Urubu-rei, ninguém vê. Ele tem duas cabeças, duas caras. Aqui e atrás, o Urubu-rei. Quando chegaram lá, Urubu-rei ficou alegre com genro, com a filha, ficou alegre. Chegou lá, aí morou. Agora ele quer conhecer o sogro dele. Não deu pra ver ele. A casa dele toda fechada, ninguém vê ele. Aí um dia o Urubu-rei queria comer ele, comer o genro. Aí falou pra filha: "Minha filha," fala os dois, né?,19 o Urubu-rei. "Minha filha, minha filha, fala pro meu genro fazer banco pra mim. Diga pro meu genro fazer banco pra $\mathrm{mim}^{20}$ assim como minha cabeça, assim como minha cabeça." Agora como é a cabeça dele, pra ele saber. Então, aí um dia encontrou com companheiro. "Que foi companheiro tá triste?" "Tô triste porque meu sogro me mandou fazer banco pra ele, [...] como cabeça dele, banco como cabeça dele. Mas eu não vi cabeça dele, eu não tenho como ver cabeça dele." "Tá bem, então amanhã meio-dia, vê se tem um buraco na parede da casa dele, buraquinho. Aí tu vai ver meio-dia, eu vou cagar em cima da cabeça dele. Aí vai chamar a filha dele e aí vai [acocá] aí tu vai ver a cabeça dele como é." Meio-dia chegou. Aí ele encostou na parede e chamou a filha dele.

Uyensî', uyensî́ o'ma wakanpîman upona / Uyensî', uyensî́ o'ma wakanpîman upona / O'ma wakanpîman upu'paipona / O'ma wakanpîman upu'paipona

[Filha, filha, o bicho fez cocô em cima de mim / Filha, filha, o bicho fez cocô em cima de mim / O bicho fez cocô na minha cabeça / O bicho fez cocô na minha cabeça]

Aí encostou lá. Filha dele, não sei nem como foi se tem luz, fósforo, não sei não, mas é a história. "Ah, cabeça dele é assim é? Tá bem, cabeça dele." Isso aí é a Osga que cagou em cima da cabeça dele. Aí ele fez banco pra ele, assim como cabeça dele. Terminou, entregou pra filha, aí filha foi e levou banco dele. "Papai, seu genro já acabou coisa, terminou de fazer banco." Está bem. Aí foi lá deu pra ele: "Tá aqui seu banco." Assim como cabeça dele. "E agora, como é que eu vou pegar ele pra mim

\footnotetext{
${ }^{19}$ As duas cabeças do Urubu-rei falavam ao mesmo tempo.

${ }^{20}$ Tenho registros de um pajé que diz que seu banco possui o formato da cabeça do Urubu-rei.
} 
comer?" Ele é sogro dele, pensou. "Minha filha, minha filha. Diga pro meu genro construir a casa em cima dessa laje aqui." "Mas como furar pedra?" Aí, tava pensando: "Como é que eu vou fazer pra furar pedra, não é outra coisa não, como furar pedra?" Aí uma pessoa encontrou com ele, um pretinhozinho. "Que foi?" "Não, estou aqui pensando, meu sogro mandou fazer, construir casa dele em cima dessa pedra, mas não tem como. Como é que eu vou cavar isso daqui?" "Tá bom." Estaca taí, encostou tudo, material tava encostado aí. "Então vamos atrás de mim. Coloca atrás de mim a estaca." Ele entrou pela pedra tchummmmm. Terminou de estacar a casa.

DF: Quem era esse pretinho?

CR: Muçunzinho. [...] Pequenininho. Muçum, aquela cobra d'água. Muçum, aquele liso, menorzinho da serra, menorzinho. Terminou a casa e não deu pra comer o genro, não. "Puxa vida, como é que eu vou comer ele agora?" Aí mandou ele pra esgotar a água do Piripiri. [...] Lago graaaande. "Diga pro meu genro derramar essa água todinha, eu quero comer os peixes daí de dentro." "Tá bom." "Não, papai disse pra você não viajar mais, não." Agora comida, que ficou magro, magro, magro. Não podia comer comida deles, só estragado. "Tá bem." Fez a barragenzinha, [...] ao redor do lago, pra água não voltar. "Poxa vida, pra derramar essa água aqui, como é que eu vou derramar sozinho." Aí os parentes encontraram ele. É muitos parentes, ele triste. Tava triste ainda. Aí contou pra ele: "Que tem compadre?" "Não eu estou assim, meu sogro me mandou pra derramar essa água aqui." "Ah, eh?" "Não sei como que eu vou derramar, não sei como que eu vou acabar, eu sozinho." Lago graaaande. "Nós vamos te ajudar, nós vamos te ajudar." Aí os passarinhozinhos, Uri, é o nome deste, Uri, em macuxi, Uri, tem os peitos amarelos. Aí os outros. Como é?

DF: Lava-bunda? Libélula?

CR: Como?

DF: Libélula? Que bate a bunda na água assim?

CR: Ahã. Aí eles iam indo, passarinho pra cá e pra cá. Derramaram lago lá, derramaram lago, derramaram. Agora convidaram anu, pássaro também. Anu, você fica em cima 
daquela árvore ali aí, quando filha deles vier de lá pra cá, pode nos avisar, que nós vamos desaparecer de repente. Ele fica sozinho aí. Aí faz: "Oioioi." Todo mundo foi embora. Ele ficou sozinho. Traziam caxiri pra ele, caxiri de todos os animais, podre, que é urubu. "Deixa aí, depois eu tomo." Mas os passarinhos traziam caxiri de milho, de milho branco. Isso aí que ele tava aguentado, caxiri de milho. Derramava, como ele trouxe, o pessoal. Aí um dia terminaram. Secou lago, mesmo, muitos, né. Aí mataram jacaré, cobra, tudo que tava dentro do lago. Deu ordem pra colocar na canoa e tampar pra apodrecer lá. Não sei quantas canoas. Tá bom agora, parente querendo comer peixe, não tem panela, não tem fogo. "E agora?" Deu vontade pra ir embora nele. "Como é que eu vou agora?" Vou fugir daqui. Matou os animais ali do lago, deixou todos num porão de canoa aí, pra apodrecer.

DF: Comida pros urubus?

CR: Comidas pros urubus, pro rei. Aí uma pessoa encontrou com ele. "Que foi compadre?" "Não, compadre, estou triste aqui, porque eu vim acompanhando a filha do urubu e agora me encontro deste jeito, desta maneira, magro, eu não como nada, eu não como nada das comidas dos urubus, não. Quero ir embora daqui, eu não sei quem vai me ajudar." "Não, eu vou te ajudar. Umbora ali?" Aí foi com ele. "Compadre, você senta aqui, aí isso aqui vai descer." Como é que diz?

DF: Aranha? Teia.

CR: Você vai descer, vai embora. Aí a teia saía lá embaixo na terra, em cima da samaúma, direto em cima da samaúma. Pronto, daí ele tirou teia dele. Aranha ajudou ele. Ele ficou lá em cima, sem ter como descer também.

DF: Preso em cima da samaúma.

CR: Eh. Aí encontrou, ele fala assim: "Achei comida pra mim, achei comida pra mim. Achei..." 21 "O que é que você quer?" "Não, tô indo, tô voltando pra casa." "Monta aqui, que aqui, eu vou te levar lá no tronco." Mas ele tava querendo comer ele.

${ }^{21}$ Fala estilizada, meio roca e roncando. 
DF: Ele não tinha nome, não? Era só um parente?

CR: Não, quem isso aí, o animal?

DF: O animal e ele também?

CR: Não, não tem não, nunca vi não. Ele montou em cima dele pra subir: "Achei comida pra mim!" Em cima da samaúma. "Achei comida pra mim!" "Vovô, é mais embaixo, vai mais embaixo, vovô." "Achei comida pra mim!" "Achei comida pra mim!" "Vai mais embaixo, vovô." Quando chegou aqui, pulou. Era a Osga que queria comer ele. Aí foi embora, deixou Osga aí, deixou tudo, deixou Urubu, deixou. Chegou na casa, encontrou mamãezinha lá. Mamãezinha em vez de dar comida pra ele devagar, porque passou muito tempo sem comer, deu comida pra ele, deu caxiri pra ele, encheu barriga. Se sentiu mal, se sentiu mal, mas ele contou essa história, como começou até o fim. Aí morreu, não aguentou porque comeu. Ficou muito tempo sem comer. [...]

DF: Onde fica o lago Piripiri? Em que lugar.

CR: Ele fica pra cá do Céu.

DF: Pra cá do Céu.

CR: Pra cá do Céu aqui, aí em cima do Céu.

A reposta final do narrador, localizando o local onde se está o Piripiriku'pa, é sintomática das principais diferenças que envolvem oralidade e textos escritos. Primeiro aponta para diferenças entre a realidade indígena e a nossa. O panton yekareme' nen, o contador de histórias, não titubeia em localizar que é no céu onde se encontra o lago. Ainda, a possibilidade de interação, de sanar dúvidas que por acaso surjam na narrativa é outro fator divergente de uma literatura escrita. $\mathrm{O}$ diálogo entre o narrador e o ouvinte é imediato, e a interação possível. Com certo contrassenso, os textos aqui apresentados estão na versão escrita. Isso, de certa forma, é um incômodo, mas a origem oral foi preservada, sua força primeira nascida da boca do yekareme' nen.

$\mathrm{O}$ taren, o eren e o panton são formas ainda em uso entre os Macuxi, apesar do contato intenso com a cultura dominante, não indígena. Muito já se perdeu (e não há outra palavra) de tarenkon, de erenkon, de pantonkon, mas ainda, como registrado pelo projeto Panton Pia' (junto, 
perto, ao lado da história), há uma diversidade significativa dessas poéticas orais. A pergunta que a comunidade científica, os próprios indígenas e a comunidade em geral devemos fazer é o que faremos com essas poéticas, ou como chamei no título, com essas poetnicidades orais. Vamos continuar fingindo que elas não existem?

\section{Referências}

AGUIAR E SILVA, Vítor Manuel (2000). Teoria da literatura. Coimbra: Almedina. ALBERTI, Verena (2004). Manual de história oral. 2. ed. Rio de Janeiro: Editora FGV.

ARMELLADA, Cesáreo de; NAPOLITANO, Carmela Bentivenga de (1975). Literaturas indígenas venezolanas. Caracas: Monte Ávila.

ARMELLADA, Cesareo de; SALAZAR, Mariano Gutierrez (2007). Diccionario pemón: pemón-castellano/castellano-pemón. Caracas: Universidad Católica Andrés Bello; Hermanos Capuchinos.

BENJAMIN, Walter (1987). O narrador. Considerações sobre a obra de Nicolai Leskov. In: BENJAMIN, Walter. Magia e técnica, arte e política: ensaios sobre literatura e história da cultura. 3. ed. São Paulo: Brasiliense.

BUTT-COLSON, Audrey Butt (1985). Routes of knowledge: an aspect of regional integration in the circum-Roraima area of the Guiana Highlands. Antropológica, Caracas, n. 63-64, p. 103-149. Disponível em: <https://goo.gl/2QkQT2>. Acesso em: 15 jan. 2017.

CAMPOS, Haroldo (2011). Da transcriação: poética e semiótica da operação tradutória. Belo Horizonte: Viva a voz (FALE/UFMG).

CASTRO, Eduardo Viveiros de (2011). A inconstância da alma selvagem. São Paulo: Cosac Naify.

COMPAGNON, Antoine (2012). O demônio da teoria: literatura e senso comum. 2. ed. Belo Horizonte: Editora da UFMG.

EAGLETON, Terry (1997). Teoria da literatura: uma introdução. 3. ed. São Paulo: Martins Fontes.

GONZÁLEZ, Mauricio Ostria (2001). Literatura oral, oralidad ficticia. Estudios Filológicos, Valdivia, n. 36, p. 71-80. Disponível em: <https://goo.gl/wBKaKX>. Acesso em: 15 jan. 2017. 
GOLDEMBERG, Deborah (2009). A concepção do I Sarau de Poéticas Indígenas por uma antropóloga escritora. Espaço Ameríndio, Porto Alegre, v. 3, n. 1, p. 4260 , jan./jun.

HAVELOCK, Eric A. (1996). A musa aprende a escrever. Lisboa: Gradiva.

KOCH-GRÜNBERG, Theodor (2006). Do Roraima ao Orinoco: observações de uma viagem pelo norte do Brasil e pela Venezuela durante os anos de 1911 a 1913. Tradução de Cristina Alberts-Franco. São Paulo: Editora da Unesp. v. 1.

OLIVEIRA, Idelvânia Rodrigues de (2014). Os Monaikó: narrativas orais e registros linguísticos. Dissertação (Mestrado em Letras) - Universidade Federal de Roraima, Boa Vista.

ONG, Walter J. (2002). Orality and literacy. New York: Routledge.

RABELO FILHO, Manoel Gomes; ARAÚJO Jacilda Barreto de (2015). A representação social do kanaimî, o piya'san e do tarenpokon. Olhares Amazônicos, Boa Vista, v. 3, n. 2, p. 627-637, jul./dez.

RISÉRIO, Antonio (1993). Textos e tribos: poéticas extraocidentais nos trópicos brasileiros. Rio de Janeiro: Imago.

SEBILLOT, Paul (1881). Littérature orale de la Haute Bretagne. Paris: Maisonneuve; Cia Éditeurs.

THURN, Everard F. im (1883). Among the indians of Guiana. London: Kegan.

WITEHEAD, Neil L. (2002). Dark shamans: Kanaimà and the poetics of violent death. Durham \& London: Duke University Press.

ZUMTHOR, Paul (1993). A letra e a voz: a literatura medieval. Tradução de Amálio Pinheiro e Jussara Pires Ferreira. São Paulo: Companhia das Letras.

Recebido em 8 de março de 2017.

Aprovado em 7 de agosto de 2017.

\section{resumo/abstract/resumen}

\section{Taren, eren e panton: poetnicidade oral Macuxi}

Devair Antonio Fiorotti

Taren, eren e panton são termos da língua macuxi para, respectivamente, palavra encantada, canto, história. Os Macuxi são indígenas caribe, que se 
autodenominam Pemon (gente), que vivem na região do circum-Roraima, na tríplice fronteira Brasil-Venezuela-Guiana Inglesa. A partir dessas três categorias, este trabalho as defende e apresenta como formas da poética oral desse povo, incomodado com o descaso em relação à existência das poéticas orais no Brasil.

Palavras-chave: taren, eren, panton, poéticas orais.

\section{Taren, eren and panton: Macuxi oral poethnicity}

\section{Devair Antonio Fiorotti}

Taren, eren and panton are terms from the Macuxi language that mean, respectively, enchanted word, song and narrative. Macuxi are Carib indians who designate themselves as Pemon (people). They live in the Circum-Roraima region, on the triple border among Brazil-Venezuela-Cooperative Republic of Guyana. This work proposes these three Macuxi terms as an expression of an oral poetics of this indigenous people, who are troubled by the disregard towards Brazilian oral poetics.

Keywords: taren, eren, panton, oral poetics.

\section{Taren, eren y panton: poetnicidad oral Macuxi}

Devair Antonio Fiorotti

Taren, eren y panton son los términos en lengua Macuxi, respectivamente para palabra encantada, canto, historia. Los Makuxi son indígenas caribe, que se llaman a sí mismos Pemon (personas) y que viven en la región del circumRoraima, en la triple frontera entre Brasil-Venezuela-Guyana Británica. A partir de estas tres categorías, este trabajo las defiende y presenta como formas de la poética oral de ese pueblo indígena, preocupado con la desatención en relación a la existencia de las poéticas orales en Brasil.

Palabras clave: taren, eren, panton, poética oral. 